\title{
The Drinking Habits of Birds
}

\section{By Seron Gordon}

$\mathrm{T}$ HE lover of birds who places a shallow dish of fresh water each morning beside the bird table and has the pleasure of seeing chaffinches, robins and other of his bird friends drink eagerly from it, may perhaps have wondered how young birds in the nest receive the moisture which is necessary to them, or how sea-birds drink.

I do not think that the young of any British birds actually drink in the nest; they receive their moisture in the food which is brought them, and it is partly no doubt because they cannot drink that the parents are so careful to shield them from the direct rays of the sun before they are feathered. It is not perhaps generally known that direct sunlight is fatal to young birds. The gannet is one of the hardiest birds, yet I have known a young gannet succumb after being left unattended in the nest for the space of rather more than an hour while the strong August sun beat down upon its small, black, naked body. Even the golden eagle, which leaves its eaglets unprotected to the snow-laden wind, builds its eyrie almost always where the nest faces north and thus is sheltered from the sun. During a recent early summer, my wife and I watched almost daily for the space of a fortnight at an eagle's eyrie from a heather hide. The eyrie was facing north-east, and the sun did not shine on it after eleven o'clock in the morning. One morning after a very cold spell the sun shone strongly on the eyrie. The morning had been dull and close, and when the sun, shortly after half past ten, suddenly emerged from one of the heavy clouds, its rays were brilliant and for once I felt comfortably warm in my hiding-place. The mother eagle was standing at the edge of the eyrie, and when the sun appeared walked over to the eaglet (which was three weeks' old and covered with thick white down) and, standing between it and the sun, slightly opened her great wings to shelter it. The sun increased in power, and gradually, in three distinct movements, she spread her wings to their fullest extent and stood quite motionless. The beauty of that picture I shall long remember. My peep-hole was not more than twelve feet from the nest, and every feather of the eagle was distinct, the great wing primaries drooping to the sides of the eyrie. The sun gradu. ally left the eyrie and when the nest was in shade the eagle folded her wings, walked to the edge of the eyrie and launched herself on the air with a sudden splendid gesture.

The young golden eagle is hatched early in May and does not take its first flight until midJuly. During all that time it never drinks, but depends for its moisture on the food brought to it-hares and grouse, rabbits, even stoats and squirrels. But does the adult eagle drink? Some observers believe that it never does so, but a stalker told me that he once came suddenly on a golden eagle bathing, if not actually drinking, in a clean pool of a hill burn, and in his words "when she had finished bathing herself she walked to the edge of the pool and shook out her feathers just like an old hen".

There may be quite a number of our land birds which do not habitually drink, and what of the great army of sea-birds that live their whole lives on the salt water? Do they drink sea-water? Or do they never drink? I do not refer to the seagulls, which spend a part of their time on land, but to the vast armies of guillemots which crowd the rock stacks in summer as they incubate their eggs on arid sunbaked ledges, to the colonies of razorbills, cormorants and shags, to the stormloving petrels and the gannets which fly tirelessly a hundred miles and more to catch a fish for the hungry family. The only water which all these birds know is the salt water of the ocean. Do they drink it or does their fishy food, saturated with moisture, supply them with liquid enough ? Even if they do not drink salt-water, they must have some means of dealing with their food, which is salt-impregnated, and would probably be fatal to a land bird. All who know the great northern diver, the guillemot, the black guillemot and other divers of the sea must be familiar with the habit of all these birds of dipping the bill constantly into the water after a dive and also when swimming. This is done whether the bird has caught a fish and swallowed it, or whether the dive has been unsuccessful, so that it cannot be to clean the bill. The impression given superficially is that the bird is drinking, but I am rather inclined to believe that it is a habit, perhaps originally adopted when cleaning the bill. It is interesting to note that when human inquirers approach a nesting place of a pair of black guillemots the birds swim rapidly backwards and forwards, calling shrilly and repeatedly dipping their bills in the water.

There is one exception to this habit of billdipping among the divers of the sea. The puffin does not dip the bill, although it is as assiduous a fisher as any. Perhaps it is because its bill, being large and clumsy, would offer too great a resistance to the water through which the bird is swimming. It can, I think, be safely concluded that this curious habit of holding the bill just beneath the surface of the sea while swimming has nothing to do with drinking.

Sea-gulls, although they pass much of their time on the sea, leave it when they wish to bathe and drink. There is one small loch beside the Atlantic where gulls are almost always to be seen bathing with relish, and they fly backwards and forwards between this loch and the sea, perhaps several times a day. 
The wild whooper swan which arrives in Britain in autumn from Iceland settles at times on the sea, but is never happy on the salt water, although its relative, the smaller Bewick's swan, passes most of the winter season on the brackish lochs and estuaries of the Hebrides. Ducks appear to drink frequently, but wild geese at their winter haunts must be able to go some time without water, for some of the sea-girt isles where they live have no fresh water upon them.

The grey or hooded crow is detested by game preservers because of its habit of stealing eggs. Especially when the grey crows have young in the nest they hunt far and wide for the eggs, not only of grouse but also of much larger birds, and I have known them suck a nest of a grey lag goose's eggs in a single day. It is possible that this egg stealing is partly to provide the young birds in the nest with as much liquid food as possible, and one can understand why young hooded crows should be able to exist without water. But the twite, which feeds its young on seeds, the siskin, the linnet and other passerine birds-how is it possible that the broods of these birds should live without water during their time in the nest? The passerine birds which feed their young on hard and dry seeds do so by regurgitation. They swallow the seeds, and later present them to their young moistened, and impregnated with their digestive saliva. Those which feed their young on insects and other juicy living food feed them directly, without regurgitation.

Dr. Glover Allen, in his book "Birds and their Attributes" referring to the drinking habits of North American birds, writes:

"In the far north water may be unobtainable throughout winter, but it may be possible for northern birds to subsist on snow. I have known pine siskins to eat snow and once watched a flock of Cedar Waxwings engaged in catching snowflakes during a storm, flying up and snapping at them as if they were insects. Here is a subject on which more information might easily be secured."

Elsewhere Dr. Allen remarks :

"A final word as to the drinking habits of birds, which have not perhaps been sufficiently studied. We have all noticed that hens and sparrows sip from a pan, raising their head between each sip as if to let the drop trickle down their throats. The quite different manner in which pigeons thrust in their bills and pump in the water like a horse cannot have escaped the attention of most. We do not know much as to the amount of water birds need and how often they drink. It is said that prospectors in desert country are often able to locate springs by watching the flights of doves or pigeons which must drink daily and fly in from the surrounding country regularly for the purpose.

"Most sea birds are known to drink salt water in preference to fresh; indeed captive gulls may die without it. Land birds, however, need fresh water. No doubt some species must go long periods without drinking, as in case of certain birds that incubate continuously, for example, the female Hornbill that is walled up in her nest cavity and fed by her mate."

In "Jungle Side", a natural history account of Ceylon, by John Still, are some interesting remarks on the drinking habits of birds. The author writes :

". . . the lovely paradise fly-catcher who nests in some garden in the nor'-east monsoon can be found passing the sou'-west as a visitor to a water-hole. Others are permanent forest dwellers, like the wonderful long-tailed robin whose song is the sweetest in all Ceylon, and another rather rare little bird who often owns a water-hole to himself, the three-toed kingfisher, whose gay habit it is to have rosy plumage where most of his tribe have blue."

Observations by trained watchers on the drinking habits of birds are, however, very meagre, and the whole fascinating subject would certainly repay more close observations.

\section{Joachim Barrande and his Palæontological Work}

\section{By $J_{A N}$ Kourha, Curator of the Barrandeum, National Museum, Prague}

A LITTLE more than fifty years ago, on A October 5, 1883, the death occurred of Joachim Barrande, who was one of the greatest palæontologists of the second half of the nineteenth century. Barrande was born on August 10, 1799, on the estate of his family at Sangues (Dept. Haute Loire). He studied at the Paris Polytechnic School. Besides lectures of a purely technical nature on bridge- and road-construction, he attended those on geology, zoology and botany. His teachers were $G$. Cuvier, A. Brongniart, de Jussieu, C. Prévost, de Blainville, G. St. Hilaire, Serres, Audouin and others.

Soon after Barrande left the Polytechnic, he was called to the French Court, to act as tutor in natural science and mathematics to the heredi. tary Prince Henri, Count Chambord, grandson of Charles X. When the Bourbon family was expelled from France, after the revolution of July 1830, Barrande also went into exile with them. After a short stay in Edinburgh, the royal family came to Bohemia, first of all living at Buštěhrad Castle (west of Prague) and then at the Castle, Prague (that is, Hradčany, the old royal castle of the Czech kings). From this time onwards, Barrande remained permanently in Prague.

In 1833 Barrande gave up his position as a tutor, and devoted himself to engineering. $\mathrm{He}$ was entrusted with the surveying of a projected line, which was a continuation of the horse route, from Krivoklát, along the River Berounka, to the coal basin of Radnice and then on to Plzen. 